Expl Cell Biol. 1986;54:I-V

\title{
Contents, Vol. 54, 1986
}

International Journal of Basic Pathology, Neoplasia, Immunology, Heterotransplantation and Differentiation

Founded 1938 as 'Schweizerische Zeitschrift für allgemeine Pathologie und Bakteriologie' by A. v. Albertini, A. Grumbach and H. Mooser, continued as 'Pathologia et Microbiologia'

Editors

Pathology

J.R. Rüttner, Zurich Neoplasia

G.V. Sherbet, Newcastle upon Tyne Immunology

H. Ramseier, Zurich Heterotransplantation

L. Helson, Wilmington, Del. Differentiation

A. Wolsky, New York, N.Y.

Co-Editors

Pathology

R. Hess, Berne M. Kyogoku, Sendai M.A. Spycher, Zurich P. Vassalli, Geneva G. Zbinden, Zurich

Neoplasia

R.C. Coombes, Sutton

D. Glaves Rapp, Buffalo, N.Y.

I.R. Hart, London

M.S. Lakshmi, Newcastle upon Tyne L. Milas, Houston, Tex. G.L. Nicolson, Houston, Tex. G.

Poste, Philadelphia, Pa. V. Schirrmacher, Heidelberg E.Sidebottom, Oxford

Immunology

H. Binz, Zurich D.G. Braun, Basel

E. Diener, Edmonton

R.T. Smith, Gainesville, Fla. J. Sprent, Philadelphia, Pa.

E. Wecker, Würzburg H. Wigzell, Stockholm R.M. Zinkernagel, Zurich

Heterotransplantation

B.C. Giovanella, Houston, Tex.

D.P. Houchens, Columbus, Ohio

I. Lefkovits, Basel

T. Nomura, Kanagawa

CO. Povlsen, Copenhagen

N.D. Reed, Bozeman, Mont.

J. Rygaard, Copenhagen

S. Shin, Bronx, N.Y.

B.C.M. Sordat, Lausanne

Differentiation

M. Balls, Nottingham

J.A.M. van den Biggelaar, Utrecht 
R. Chandebois, Marseille

G. Csaba, Budapest

S. Løvtrup, Umeå

D.J. Pizzarello, New York, N.Y.

S. Ranzi, Milan

T. Yamada, Lausanne

S. Karger $\cdot$ Medical and Scientific Publishers

Basel · München · Paris · London · New York · New Delhi · Singapore · Tokyo · Sydney Drug Dosage

The authors and the publisher have exerted every effort to ensure that drug selection and dosage set forth in this text are in accord with current recommendations and practice at the time of publication. However, in view of ongoing research, changes in government regulations, and the constant flow of information relating to drug therapy and drug reactions, the reader is urged to check the package insert for each drug for any change in indications and dosage and for added warnings and precautions. This is particularly important when the recommended agent is a new and/or infrequently employed drug.

All rights reserved.

No part of this publication may be translated into other languages, reproduced or utilized in any form or by any means, electronic or mechanical, including photocopying, recording, microcopying, or by any information storage and retrieval system, without permission in writing from the publisher or, in the case of photocopying, direct payment of a specified fee to the Copyright Clearance Center (see 'Information for Readers and Subscribers').

(C) Copyright 1986 by

S. Karger AG, P.O. Box, CH-4009 Basel (Switzerland) Printed in Switzerland by Thür AG Offsetdruck, Pratteln

Contents Vol. 54,1986

No. 1 Characterization of the Giant Myofíber in Bovine Skeletal Muscle

Sink, J.D.; Mann, O.M.; Turgut, H 1

In vivo Effect of DL- $\alpha$-Difluoromethylornithine on the Polyamine and Nucleotide Phos phate Metabolism in P388/S Leukemia Cells

Kremmer, T.; Boldizsár, M.; Holczinger, L 8

Use of Donor-Specific T-Cell Lines for Monitoring of Human Allograft Recipients. I.

Demonstration of IgG Binding to Autologous TCL

Huber, C; Irschik, E.; Leiter, E.; Binz, H.; Niederwieser, D.; Spielberger, M.; Kathrein, H.; Schönitzer, D.; Margreiter, R 16

Hydrocortisone Promotes the Neodifferentiation of Kirsten Murine Sarcoma Virus

Transformed Human Skin Fibroblasts to Adipose Cells: Relevance to Oncogenic

Mechanisms

Kopelovich, L.; Rich, R.F.; Wallace, A.L 25

Human Lactic Dehydrogenase as a Marker for Monitoring the Growth of Prostatic Carci noma in Nude Mice

Heckl, W.; Fogh, J 34

Low Frequencies of Apparently Fragile X Chromosomes in Normal Control Cultures: A Possible Explanation

Jenkins, E.C.; Brown, W.T.; Brooks, J.; Duncan, C.J.; Sanz, M.M.; Silverman, W.P.; Lele, K.P.; Masia, A.; Katz, E.; Lubin, R.A.; Nolin, S.L 40 
Influence of Deciliation and Ciliary Regeneration on Hormonal Imprinting in Tetrahymena. Observations on the 'Localization' of Imprinting

Csaba, G.; Darvas, Z.; Kovács, P.; Madarász, B 49

Changes in Activity of the Regulatory Glycolytic Enzymes and of the Pyruvate-Dehydrogenase Complex during the Development of Xenopus laevis

Raddatz, E.; Løvtrup-Rein, H 53

No. 2 Monoclonal Antibodies to Human Cytokeratins: Application to Various Epithelial and Mesothelial Cells

Lang, A.B.; Odermatt, B.F.; Ruettner, J.R 61

Cytoskeletal Proteins as Tissue-Specific Markers in Cytopathology

Puts, J.J.G.; Vooijs, G.P.; Huysmans, A.; van Aspert, A.; Ramaekers, F.C.S 73

Loss and Reappearance of Transferrin Receptors in Human Leukemic Cell Lines

Petraki, H.; Ioannides, C.G.; Filli, S.; Papamichail, M 80

Histochemical Detection of Ubiquinone in Neutrophil Polymorphonuclear Leucocyte

Granules

Lee, J.A. . $\quad 89$

Ultrastructural Localization of Acid Phosphatase in Germ Cells of Chick Embryo Left

Ovary

Civinini, A.; Mastrolia, L 94

IV

Contents

Cyclic AMP and Cell Differentiation in Amphibian Embryonic Explants

Mattsson, M.-O.; Løvtrup, S 106

Immunocytochemical Localization of Actin in the Sperm Head of Talpa europaea (Insectivora)

Castellani-Ceresa, L.; Colombo, R.; Cotelli, F.; Lora-Lamia-Donin, C

Book Review 119

Announcements $\quad 120$

No. 3 Effects of Hyperinsulinism and of Diabetes on Proteoglycans of the Intervertebral Disc in Weanling Sand Rats

Silberberg, R.; Adler, J.H.; Meier-Ruge, W 121

Modulation of Tumor Cell Motility by Prostaglandins and Inhibitors of Prostaglandin

Synthesis

He, X.; Fligiel, S.E.G.; Varani, J 128

Effect of Melphalan on Growth Curves and Cell Cycle Distribution of Four Human Small

Cell Carcinomas of the Lung Grown in Nude Mice

Engelholm, S.A.; Spang-Thomsen, M.; Vindeløv, L.L.; Brünner, N 138

Quantitative Evaluation of Anticancer Agents against Human Melanoma Cells Implanted

in Nude Mice

Lockshin, A.; Giovanella, B.C.; Stehlin, J.S., Jr

Antigen Presentation in Human Autoimmune Thyroid Disease

De Bernardo, E.; Davies, T.F 155

Modified Distribution of Epidermal Glycoproteins in the Nude Mouse

Brysk, M.M.; Miller, J.; Chen, S.-J.; Rajaraman, S 163

Communication between Primary Endoderm and Mesoderm for Erythroblast Differentiation in

Early Chick Blastoderm 
Zagris, N $\quad 170$

Book Reviews $\quad 175$

No. 4 Collagen Synthesis in Growing Human Skin Fibroblasts

Kirchhofer, D.; Reinhardt, C.A.; Zbinden, G 177

Collagen Production by Rat Liver Fat-Storing Cells in Primary Culture

Kawase, T.; Shiratori, Y.; Sugimoto, T 183

Cellular Growth Modulation. I. Effects of Extracellular Matrix and Tumor Cell Condi

tioned Medium

Hakim, A.A 193

A High-Affinity Monoclonal Antibody (GIF-1) to Human Gamma-Interferon: Neutralization of Interferon Mediated Inhibition of Retrovirus Production and 2'-5' (A) Synthe-tase Induction

Feit, C; Sen, G.; Bartal, A.H.; Hirshaut, Y.; Anderson, S.L.; Millet, S.K.; Rubin, B.Y. 212

Cloning of Cells from Synovial Membrane for the Investigation of Rheumatoid Arthritis

Andreasen, A.; Jensen, P.K.A.; Jakobsen, E 220

Neuraminidase and Hematopoietic Factors from Human Urine

Shimizu, T.; Noguchi, J.; Schuebel, K.; Miyake, T.; Murphy, M.J., Jr 225

Book Reviews 234

Contents

$\mathrm{V}$

No. 5-6 Comparison of Exogenous Growth Stimuli for Chemically Transformed Cells: Growth Factors, Serum and Cocultures

Holzer, C; Maier, P.; Zbinden, G 237

Potentiated Susceptibility of Ascites Tumor to Acyl Derivatives of Ascorbate Caused by

Balanced Hydrophobicity in the Molecule

Miwa, N.; Yamazaki, H 245

Murine Lymphocyte and Embryonal Carcinoma Cell Surface Antigens Recognised by Rabbit

Anti-Murine Embryonal Carcinoma Serum

Stern, P.L.; Beresford, N.A.; Bell, S.M.; Thompson, S 250

Description of and Treatment to Inhibit the Rejection of Human Split-Thickness Skin

Grafts by Congenitally Athymic (Nude) Rats

Eilhar, A.; Wojciechowski, Z.J.; Piepkorn, M.W.; Spangrude, G.J.; Roberts, L.K.;

Krueger, E.E

Colony Formation of Granulocyte (CFU-g) and Macrophage (CFU-m) Precursors in

Serum- and Albumin-Free Culture: Effect of Transferrin on Clonal Growth

Iizuka, Y.; Murphy, M.J., Jr 275

Biochemical Properties of Human Urinary Megakaryocyte Colony-Stimulating Factor and Erythropoietin: The Role of Sulfhydryl Groups and Disulfide Bonds

Shimizu, T.; Miyake, T.; Pilch, A.M.; Mantel, C; Murphy, M.J., Jr 281

Retinoic Acid-Induced Differentiation of Human Neuroblastoma: A Cell Variant System

Showing Two Distinct Responses

Sidell, N.; Sarafian, T.; Kelly, M.; Tsuchida, T.; Haussler, M 287

Embryogenesis of Stratified Squamous Epithelium. I. Tissue-Specific Expression of Keratin

Proteins

Shuler, C.F.; Schwartz, S.A 301

Embryogenesis of Stratified Squamous Epithelium. II. Developmental Stage-Specific Immunoreactivity of Keratins 
Shuler, C.F.; Schwartz, S.A 310

Human Embryonic Liver Cell Differentiation. I. Changes in Specific mRNA Synthesis Correlates with Parameters Signaling Oncologic Alterations

Hakim, A.A.; Siraki, CM.; Dube, V.E 319

Studies into Disturbing Receptor 'Memory' in a Unicellular (Tetrahymena) Model System:

Changes in the Imprinting Potential on Exposure to Combinations of Related and

Unrelated Hormones

Csaba, G.; Kovács, P 333

Expression of Epidermal Differentiation Antigens in Cultures of Interspecific Somatic

Hybrids (Human Keratinocytes X Mouse Fibroblasts 3T3-4E)

Lizard, G.; Lery, X.; Chardonnet, Y.; Viac, J.; Fargier, M.-C; Thivolet, J 338

Publisher's Note 346

Author Index 347

349

Subject Index 